\title{
Influence of the Edge Effect on a Soil Seed Bank of a Natural Fragment in the Atlantic Forest
}

\section{Felipe Santana Machado', Ana Cristina Magalhães de França², Rubens Manoel dos Santos', Rosângela Alves Tristão Borém² \& Luiz Roberto Guimarães Guilherme ${ }^{3}$}

\author{
' Universidade Federal de Lavras, Departamento de Ciências Florestais, Caixa Postal 3037, CEP 37200-000, Lavras, Minas Gerais, Brasil. \\ epilefsama@hotmail.com \\ 2 Universidade Federal de Lavras, Departamento de Biologia, Caixa Postal 3037, CEP 37200-000, Lavras, Minas Gerais, Brasil. \\ ${ }^{3}$ Universidade Federal de Lavras, Departamento de Ciências do Solo, Caixa Postal 3037, CEP 37200-000, Lavras, Minas Gerais, Brasil.
}

Recebido em 25.1.2016

Aceito em 04.VIII.2017

DOI $10.21826 / 2446-8231201772211$

\begin{abstract}
The edge effect is defined as the change of biotic and abiotic characteristics in the first meters of a forest fragment from the edge towards its interior. In fragments formed by human activities, this change generates increased richness and abundance, as well as changes in the structure of the forest species of soil seed bank in the border region. This study demonstrates that in natural fragments of cloud forests, the abundance and richness positively influence the linear relation from the edge to interior, mainly by distances of 120 and 180 meters from the edge. This effect can be a result of new plant growth, or 'pioneer' occupation in gaps in the forests generated by large fallen trees.
\end{abstract}

Keywords: conservation, edge relationship, protected area

RESUMO - Influência do efeito de borda sob o banco de sementes do solo de floresta natural na Mata Atlântica. O efeito de borda é a mudança de características bióticas e abióticas nos primeiros metros de um fragmento florestal da borda para seu interior. Em fragmentos formados pelas atividades humanas essa mudança gera aumento da riqueza e abundância, bem como a mudança da estrutura do banco de sementes do solo na região de borda. Contudo, o presente estudo demonstra que em fragmentos naturais, como as florestas nebulares, a abundância e a riqueza influenciam positivamente a relação linear da borda para o interior, principalmente pelas distancias de 120 e 180 metros da borda. Esse efeito pode ser resultado da ocupação de pioneiras em lacunas deixadas por grandes árvores caídas no meio do fragmento.

Palavras-Chave: área protegida, conservação, relação borda

\section{INTRODUCTION}

The Atlantic domain extends mainly across the Brazilian coast. Its coverage goes from the southeast of the state of Rio Grande do Sul to the northeast of the state of Rio Grande do Norte (Ab'Saber 2000). This domain is considered a hotspot of biodiversity and presents high biodiversity and an endangered status (Myers et al. 2000, Mittermeier et al. 2005). The Atlantic Forest has retained approximately $11 \%$ of its total area (Ribeiro et al. 2009) and despite the reduction in size, this domain hosts one of the greatest biological diversity in the world (see species in relation to the area in Myers et al. 2000).

The deforestation and habitat fragmentation are the main threats. These actions drastically reduce forest areas, forming a large mosaic of remnants. These forest remnants may differ in structure, with conditions of the original forest merging with the surrounding habitat. These regions, which have characteristics of the two habitats, are considered edge regions, and the term that designates the conditions within this band of vegetation is the "edge effect" (Murcia 1995).
The edge effect is one of the most discussed ecological phenomena in scientific articles (Murcia 1995, Stevens \& Husband 1998, Cubiña \& Aide 2001, Laurance et al. 2002).

The modifications brought by the edge condition can alter forest structure, induced by primary plant production, which in a few years will result in the formation of a plant framework (Murcia 1995). This is directly reflected in the combination of seeds available in the soil. In fact, there is a rich selection of pioneer species in the soil seed bank that exhibit rapid development (Caldato et al. 1996, Baider et al. 1999, Monaco et al. 2003, Fisher et al. 2009, Soares \& Almeida 2011), favoring quick regeneration in situations in which forest recovery is necessary (Vespa et al. 2014) after a stochastic natural or manmade event.

The soil seed bank is a collection of viable seeds in the soil, available after stochastic events that require recovery of disturbed areas (Martins \& Engel 2007). It is a dynamic system since the inlet (in the forest system or not) and seed germination are fast (Lindner 2009) and constant, and some of these can remain in the soil for more than one year (Caldato et al. 1996). Inventories consist of species 
of the present vegetation; earlier successional stages of species and species that were never present in the area but were dispersed by some kind of organism or abiotic agents (Sorreano 2002, Vespa et al. 2014).

There are few studies that deal with the influence of the edge effect on the soil seed bank that is available in manmade forest fragments, and the situation is even worse when considering forest fragments of natural origin. For this study, the natural fragment had no human action, and instead, the action of formation is the result of weather, geological changes, and soil, among other aspects. Cloud Forests are examples of this kind of forest, because their limits are well defined by natural grasslands. In contrast, there is currently a concern over human destructive activity in regard to natural resources, and most of the studies focus on fragments that were modified by human activity (e.g. Cubiña \& Aide 2001, Melo et al. 2007).

The objective of this study was to present and analyze the plant diversity of the soil seed bank, correlating it with the edge effect in natural fragment, a cloud forest. We hypothesized that richness and abundance are increased from the interior to the edge, and that composition and structure do not remain the same, but have been randomly modified from the edge.

\section{MATERIAL AND METHODS}

\section{Study area}

The study was performed at the Parque Estadual do Ibitipoca (Ibitipoca State Park) (PEI), in the coordinates $21^{\circ} 40^{\prime}-21^{\circ} 44^{\prime} \mathrm{S}$ and $43^{\circ} 52^{\prime}-43^{\circ} 55^{\prime} \mathrm{W}$. In addition of being one of the most visited Protected Areas in the Brazilian territory, the park is considered by Ururahy et al. (1983) a Highland Ecological Refuge for vegetation, especially since it is within the Serra da Mantiqueira range and has a different landscape from its surroundings, favoring the establishment of a lattice type drainage network, in parallel form (Fontes 1997), which leads to the formation of natural lakes.

Mata Grande has the largest forest area of the PEI with 90 hectares surrounded by natural grasslands over rocky terrain (Carvalho et al. 2000), and in some parts is dominated by Eremanthus erythropappus (DC.) McLeisch. The vegetation is classified as Cloud Forest and its plant diversity is described by Fontes (1997), which is represented by 199 species with predominance of the families Myrtaceae, Lauraceae and Rubiaceae, and the most important genera are Miconia Ruiz \& Pav., Ocotea Aubl. and Solanum L..

The climate in the region according to Koppen is $\mathrm{Cwb}$, a temperate highlight tropical climate with mild summers. The average annual rainfall is $1,395 \mathrm{~mm}$ and average annual temperature ranges from 21.5 to $36^{\circ} \mathrm{C}$ in the summer, and from 2 to $14.5^{\circ} \mathrm{C}$ in the winter (Dias et al. 2002).

\section{Sampling design}

The soil seed bank was evaluated in three linear transects in the Mata Grande of the PEI. The transects were 50 meters equidistant and perpendicular to the forest edge. The limit of forest edge was defined between the limit of the natural grassland and forest environment. Seven collection sites were allocated in each transect and two subsamples were collected at each point. Each collect point was 30 meters apart from the others. The transects started at the edge (meter zero) and finished in the middle of forest. The subsamples were pooled in a single sample to perform statistical tests.

Sampling was performed using a metal template with dimensions of $25 \times 25 \times 10 \mathrm{~cm}$ for extraction of litter and $10 \mathrm{~cm}$ of soil. The collection of 42 subsamples resulted in a volume of $131,250 \mathrm{~cm}^{3}$ of soil from an area of $0.625 \mathrm{~m}^{2}$. The soil and litter samples were homogenized and placed in plastic black bags, labeled and taken to a greenhouse. The temperature was controlled between $25^{\circ} \mathrm{C}$ and $30^{\circ} \mathrm{C}$ and relative humidity $80 \%$ and $85 \%$. The soil collected was used as base to germination tests. Germination was carried out in plastic trays with dimensions of $44 \times 27.6$ $\mathrm{x} 7.6 \mathrm{~cm}$ and the material was irrigated every morning until the evaluation of the experiment, which occurred 180 days after extraction of the soil seed bank. The germinated seedlings were identified by specialists and compared with the plant diversity described by Fontes (1997).

\section{Statistical analyses}

Individual plants that emerged from the soil seed bank at the end of 180 days were counted. Histograms of the richness and abundance were made for each distance. In order to evaluate if the richness and abundance is reduced or increased in relation to the edge, linear regressions were used in the soil seed bank at each distance range (Zar 1984). The structure of diversity of soil seed bank at different distances was compared by non-metric multidimensional scaling (NMDS). The Bray-Curtis index of dissimilarity was determined. The significance of differences in the composition indicated by NMDS was tested by one-way analysis of similarity (ANOSIM) (Clarke 1993). The level of significance for all analyses was $5 \%$.

\section{RESULTS}

There were 628 seedlings of 46 species belonging to 22 botanical families in the PEI soil seed bank (Table 1). The density was 1,005 seedlings $\mathrm{m}^{2}$. Four species of seedlings were not possible to identify and were classified as morphotypes. The richest families were Solanaceae (22.92\%), Asteraceae (20.38\%) and Rubiaceae (17.83\%); and the species with the greatest number of germinations were Solanum asperum Rich. (12.1\%), Cordiera concolor (10.19\%), Eremanthus erythropappus (DC.) McLeisch. $(8.28 \%)$ and Casearia decandra Jacq. (8.28\%), in that order.

The histograms showed a high richness and abundance in the distance of 120 meters (Figs. 1A, 1B).

Linear regression between the richness of the soil seed bank and the distance from the forest edge to its interior 
Table 1. Species list, families, and sucessional stage from soil seed bank from Mata Grande of the PEI. The "unrated" represents the species without classification in successional stage.

\begin{tabular}{|c|c|}
\hline Family/Specie & Successional Stage \\
\hline \multicolumn{2}{|l|}{ Annonaceae } \\
\hline Guatteria australis A. St.-Hil & Secondary initial \\
\hline \multicolumn{2}{|l|}{ Arecaceae } \\
\hline Geonoma schottiana Mart. & Secondary initial \\
\hline \multicolumn{2}{|l|}{ Asteraceae } \\
\hline Asteracea sp. 1 & Pioneer \\
\hline Baccharis dentata (Vell.) G.M. Barroso. & Pioneer \\
\hline B. serrulata Pers. & Pioneer \\
\hline Baccharis sp. & Pioneer \\
\hline Eremanthus erythropappus (DC.) MacLeish & Pioneer \\
\hline Eupatorium ganophyllum Mattf. & Unrated \\
\hline Piptocarpha macropoda (DC.) Baker & Pioneer \\
\hline \multicolumn{2}{|l|}{ Cecropiaceae } \\
\hline Cecropia hololeuca Miq. & Pioneer \\
\hline \multicolumn{2}{|l|}{ Celastraceae } \\
\hline Maytenus salicifolia Reissek & Late secondary \\
\hline \multicolumn{2}{|l|}{ Cestrineae } \\
\hline Cestrum laevigatum Schltdl. & Late secondary \\
\hline \multicolumn{2}{|l|}{ Ciperaceae } \\
\hline Ciperaceae sp.1 & Pioneer \\
\hline \multicolumn{2}{|l|}{ Euphorbiaceae } \\
\hline Alchornea triplinervia (Sprengel) Müller Argoviensis & Secondary initial \\
\hline Sapium granulosum (Vell.) Pax & Pioneer \\
\hline \multicolumn{2}{|l|}{ Flacourtiaceae } \\
\hline Carpotroche brasiliensis Endl. & Late secondary \\
\hline \multicolumn{2}{|l|}{ Ilicineae } \\
\hline Ilex conocarpa Reissek & Unrated \\
\hline \multicolumn{2}{|l|}{ Lamiaceae } \\
\hline Hyptidendrum asperrimum & Unrated \\
\hline \multicolumn{2}{|l|}{ Lauraceae } \\
\hline Criptocaria aschersoniana Meg. & Late secondary \\
\hline \multicolumn{2}{|l|}{ Melastomataceae } \\
\hline Miconia sp. & Pioneer \\
\hline Tibouchina stenocarpa (Schrank and Mart. Ex DC.) Cogn & Pioneer \\
\hline \multicolumn{2}{|l|}{ Myrsinaceae } \\
\hline Myrsine umbellata Mart. & Secondary initial \\
\hline \multicolumn{2}{|l|}{ Oxalidaceae } \\
\hline Oxalis sp.1 & Unrated \\
\hline Oxalis sp.2 & Unrated \\
\hline \multicolumn{2}{|l|}{ Penthaphylacaceae } \\
\hline Ternstroemia brasiliensis Cambess. & Secondary initial \\
\hline \multicolumn{2}{|l|}{ Poaceae } \\
\hline Chusquea sp. & Unrated \\
\hline Poaceae sp.1 & Pioneer \\
\hline \multicolumn{2}{|l|}{ Rubiaceae } \\
\hline Borreria sp. & Pioneer \\
\hline Cordiera concolor (Cham.) Kuntze & Unrated \\
\hline Landerbergia sp. & Unrated \\
\hline Psychotria deflexa DC. & Secondary initial \\
\hline P. vellosiana Bent & Late secondary \\
\hline \multicolumn{2}{|l|}{ Salicaceae } \\
\hline Casearia decandra Jacq. & Secondary initial \\
\hline Sapindaceae & \\
\hline Serjania sp. & Pioneer \\
\hline Toulicia subsquamulata Radlk. & Unrated \\
\hline Solanaceae & \\
\hline Solanum swartzianum Roem. and Schult. & Secondary initial \\
\hline
\end{tabular}


Table 1. Cont.

\begin{tabular}{lc}
\hline Family/ Specie & Successional Stage \\
\hline S. asperum L. C. Rich. & Late secondary \\
S. granuloso-leprosum Dunal & Pioneer \\
S. pseudochina Spreng. & Pioneer \\
Solanum sp. & Pioneer \\
S. bullatum Vell. & Secondary initial \\
Verbenaceae & Pioneer \\
Duranta vestita Cham. & - \\
Unidentified & - \\
Morphotype $\mathrm{sp} .1$ & - \\
Morphotype $\mathrm{sp} .2$ & - \\
Morphotype $\mathrm{sp.} 3$ & - \\
Pteridofita $\mathrm{sp} .1$ & \\
\hline
\end{tabular}

increased significantly $(r=0.296 ; p<0.05)$. Therefore, by moving away from the border region between the grassland and the forest toward the interior of the fragment, the species richness increases (Fig. 2A). Linear regression between abundance of the soil seed bank and the distance from the edge to the interior had no significant reduction ( $\mathrm{r}$ $=0.104 ; p>0.05$ ). Therefore, abundance is similar among the different distances, but there is a small decrease from the edge to the interior of the forest (Fig. 2B).

The structure of the soil seed bank of the PEI plant species showed a significant difference according to ANOSIM $(\mathrm{R}=0.19, \mathrm{p}<0.01)$. However, NMDS did not show visible separation between the points of the twodimensional map (Fig. 3). The ANOSIM pairwise tests between the distances showed that only the comparisons between the distances 0-60, 0-90, 0-150, 0-180, 30-150, $60-150,90-150$ and $150-180$ were significantly different $(\mathrm{p} \leq 0.01)$ (Table 2).

\section{DISCUSSION}

The most representative families and genera in the soil seed bank are in agreement with the diversity of PEI, because the Solanaceae, Asteraceae and Rubiaceae families and the Solanum L. and Eremanthus Less. genera stand out in this study both with the soil seed bank and in the floristic diversity described by Fontes (1997).

The edges of the forest fragments have a strong influence on the richness and abundance of the soil seed bank (Cubiña \& Aide 2001), being considered an indirect biological effect (Murcia 1995). By being an indirect effect resulting from changes in biotic and abiotic parameters in the transitional range of forest environments, the edge effect has an influence on various aspects such as matrix, fragment size, species composition (Vespa et al. 2014), degree of closure and origin of formation (natural or disturbed). Natural environments tend to have a less pronounced edge effect primarily because their composition produces a high obstruction against external elements (Didhan \& Lawton 1999).

The forest edge effect of natural origin showed peculiarities because the richness of plant species has a decreasing linear relation from the edge to the interior, even with a low $r$ value, which shows a poor correlation between the observed variables. Nevertheless, this relation contradicts the idea that the edge acts as a barrier that accumulates
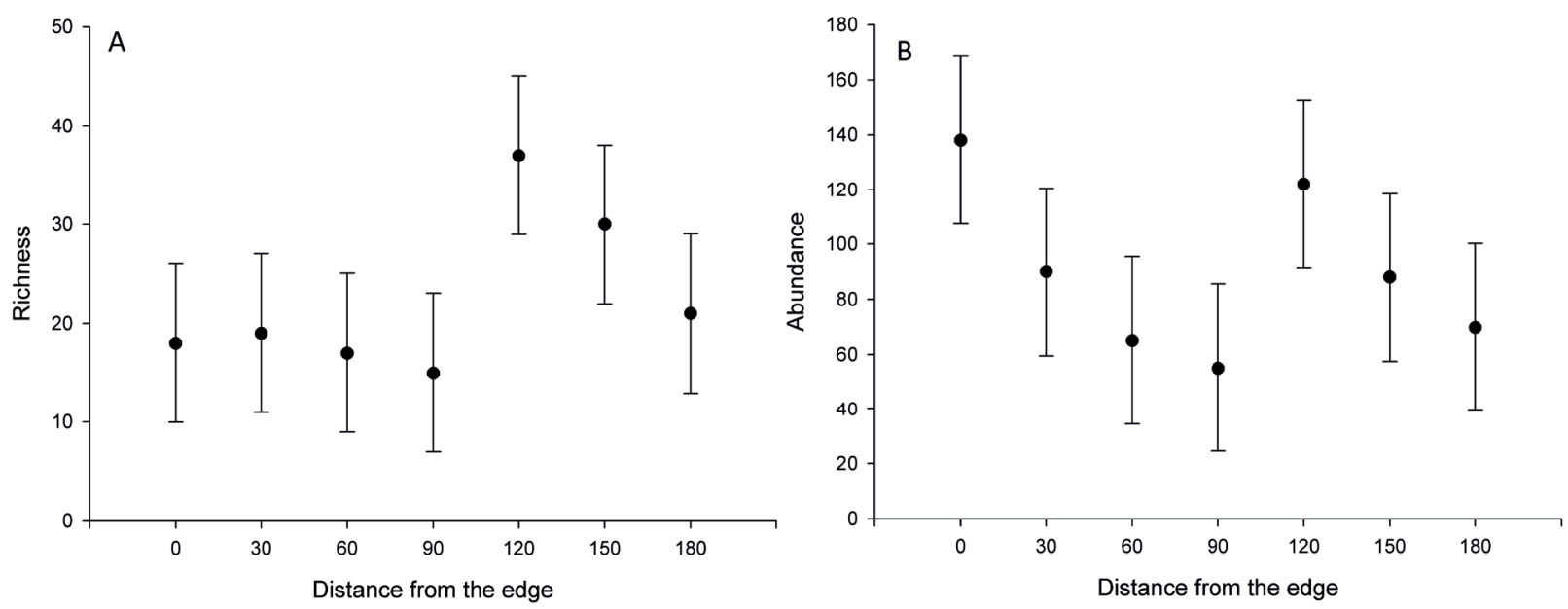

Figs. 1 A, B . A. Richness and B. abundance of the soil seed bank in relation to the edge from Mata Grande of the PEI. 

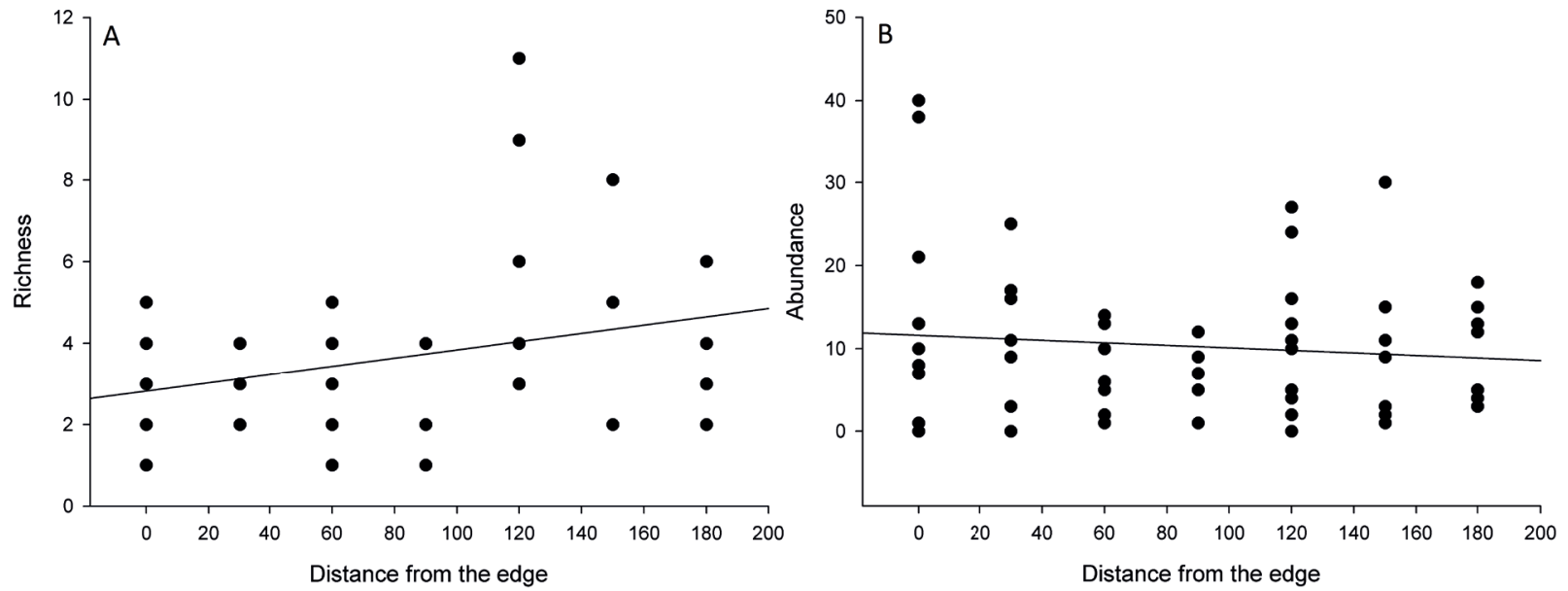

Figs. 2 A, B. A Linear regression of the richness and B. abundance of the soil seed bank in relation to the edge from Mata Grande of the PEI ( $y=A x+B)$.

propagules (Ries et al. 2004). However, the results and interpretation of Figure 1 is apparently dependent on the richest observed in the distance of 120 meters from the edge. In 150 and 180 meters the values decreased.

The abundance responds differently because there was no significant linear relation to abundance at different distances. This is a result of distances 120 and 180 meters, and for richness. This characteristic corroborates with other studies (Caldato et al. 1996, Baider et al. 1999, Monaco et al. 2003, Melo et al. 2007, Fisher et al. 2009, Soares \& Almeida 2011, Silva et al. 2012) that affirm that the soil seed bank contains pioneer and rapid developing species in most of the evaluated samples, regardless the location in which it was extracted, providing a primary stage of succession.

These results (richness and abundance) collaborate with increased diversity, due to the accumulation of seeds of different successional stages in forest clearings opened by stochastic events. Carvalho et al. (2000) noticed the

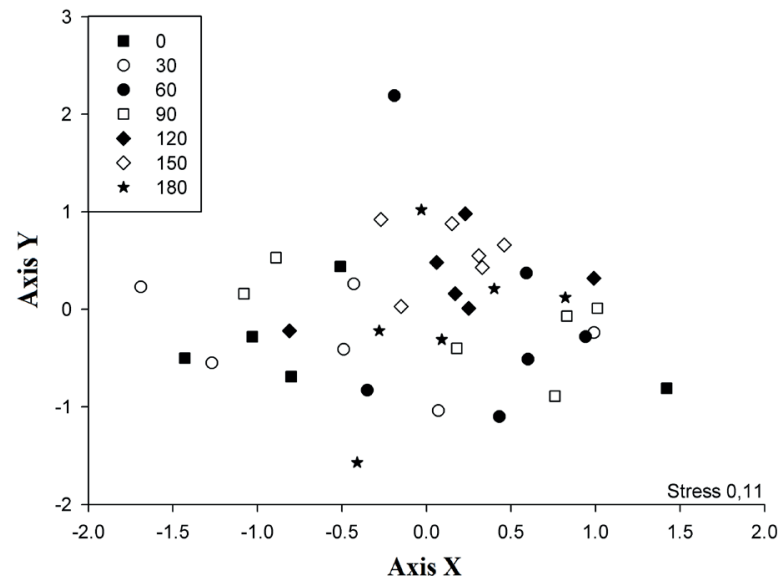

Fig. 3 NMDS of the composition of the soil seed bank differences in distances from the edge from Mata Grande of the PEI. presence of natural edge plant species dispersed throughout large gaps by birds that are typical of these edge areas. Therefore, the sum of these diversities would explain the richness increase of the soil seed bank found in this study. The same authors point out the importance of immature and mature forests in the process of rebuilding cloud forests, which increase the environmental complexity, especially through fruit production accentuated in gaps in the forest canopy by genera such as Psychotria L. and Cestrum L..

The dissimilarity found at the different distances from the edge of the forest fragment does not corroborate with the study of Silva et al. (2012), because the soil seed bank undergoes rapid reduction in abundance and richness due to short viability, thus generating dissimilarity among the areas at different distances from the edge of the forest fragment. Different herbs, shrubs and vines among the ranges of distance from the edge (Melo et al. 2007) may favor dissimilarity among the areas.

The soil seed bank is associated with their successional property floristic replacement. Monaco et al. (2003) and Sandeville Jr. (2010) comment that forest sources increment the seed rain in places where the soil seed bank is not sufficient for recovering an altered forest system. Furthermore, this study corroborates with Kalamees \& Zobel (1998), Rico-Gray \& Garcia-Franco (1992) and Milberg (1995) that mention the importance of seed bank for replacement in different degrees of succession, similarly as mentioned by Carvalho et al. (2000) on stochastic events such as natural gaps by large falling trees inside the forest.

It was concluded that in natural fragments, such as cloud forests of Atlantic Forest, the species richness and abundance influences the linear relation from the edge to its interior, mainly by distances of 120 and 180 meters from the edge. This effect can be a result of occupation by pioneers in gaps in the forests generated by large fallen trees, proving the influence of the edge effect in the fragment. The composition and structure are changed at each range edge distance. 
Table 2. ANOSIM pairwise between different distances (first column) of soil seed bank from Mata Grande of the PEI.

*Represents significant values.

\begin{tabular}{lcc}
\hline Groups & $\mathrm{R}$ & $\mathrm{P}$ \\
\hline $0-30$ & -0.095 & 0.794 \\
$0-60$ & 0.376 & $* 0.017$ \\
$0-90$ & 0.331 & $* 0.019$ \\
$0-120$ & 0.443 & $* 0.019$ \\
$0-150$ & 0.736 & $* 0.002$ \\
$0-180$ & 0.309 & $* 0.017$ \\
$30-60$ & -0.029 & 0.565 \\
$30-90$ & -0.014 & 0.532 \\
$30-120$ & 0.118 & 0.154 \\
$30-150$ & 0.424 & $* 0.004$ \\
$30-180$ & 0.128 & 0.126 \\
$60-90$ & -0.068 & 0.725 \\
$60-120$ & 0.123 & 0.136 \\
$60-150$ & 0.453 & $* 0.004$ \\
$60-180$ & 0.064 & 0.255 \\
$90-120$ & 0.064 & 0.255 \\
$90-150$ & 0.52 & $* 0.002$ \\
$90-180$ & -0.021 & 0.526 \\
$120-150$ & 0.145 & 0.063 \\
$120-180$ & 0.031 & 0.39 \\
$150-180$ & 0.219 &
\end{tabular}

This research presents the limitation of finding forest fragments of natural origin, unlike the fragments formed by human action, as found in PEI. For this reason, we believe that new research of this type should be performed as soon as this paper becomes a reference and extrapolated to other forest fragments, with emphasis on Cloud Forest fragments. Furthermore, this study also contributes to future conservation strategies by describing seed diversity in the soil and by generating ecological data of natural edge effect, which promotes a better understanding of the possibilities for the recovery/restoration of forest areas.

\section{ACKNOWLEDGMENTS}

The authors gratefully thank the Post-Graduate Program in Applied Ecology of the University of Lavras, Fundação de Amparo à Pesquisa de Minas Gerais for funding part of the activities and the Instituto Estadual de Florestas, Minas Gerais.

\section{REFERENCES}

Ab'Sáber, A.N. 2000. The Natural Organization of Brazilian Inter and Subtropical Landscapes. Revista do Instituto Geológico 21(1-2): 57-70. Doi: http://dx.doi.org/10.5935/0100-929X.20000005

Baider, C., Tabarelli, M. \& Mantovani, W. 1999. Banco de sementes de um trecho de Floresta Atlântica Montana (São Paulo, Brasil). Revista Brasileira de Biologia 59(2): 319-328. Doi: http://dx.doi. org/10.1590/S0034-71081999000200014.

Caldato, S.L., Floss, P.A., Croce, D.M. \& Longhi, S.J. 1996. Estudo da regeneração natural, banco de sementes e chuva de sementes na reserva genética Floresta de Caçador, SC. Ciência Florestal 6(1): 27-38.

Carvalho, L.M.T., Fontes, M.A.L. \& Oliveira-Filho, A.T. 2000. Tree species distribution in canopy gaps and mature Forest in an area of cloud Forest of the Ibitipoca range, south-eastern Brazil. Plant Ecology 149: 9-22. Doi: http://dx.doi.org/10.1023/A:1009836810707.

Clarke, K.R. 1993. Nonparametric analysis of changes in community structure. Australian Journal of Ecology 18: 117-143. Doi: http:// dx.doi.org/10.1111/j.1442-9993.1993.tb00438.x.

Cubiña, A. \& Aide, T.M. 2001. The effect of distance from forest edge on seed rain and soil seed bank in a tropical pasture. Biotropica 33(2): 260-267. Doi: http://dx.doi.org/10.1111/j.1744-7429.2001.tb00177.x.

Dias, H.C.T., Fernandes Filho, E.I., Schaefer, C.E.G.R., Fontes, L.E.F. \& Ventorim, L.B. 2002. Geoambientes do Parque Estadual do Ibitipoca, município de Lima Duarte-MG. Revista Árvore 26:777-786. Doi: http://dx.doi.org/10.1590/S0100-84042011000200012

Didham, R.K. \& Lawton, J.H. 1999. Edge structure determines the magnitude of changes in microclimate and vegetation structure in tropical forest fragments. Biotropica 31(1): 17-30. Doi: http://dx.doi. org/10.1111/j.1744-7429.1999.tb00113.x.

Fisher, J.L., Loneragan, W.A., Dixon, K. \& Veneklaas, E.J. 2009. Soil seed bank compositional change constrains biodiversity in an invaded species-rich woodland. Biological Conservation 142: 256-269. Doi: http://dx.doi.org/10.1016/j.biocon.2008.10.019.

Fontes, M.A.L. 1997. Análise da composição florística das florestas nebulares do Parque Estadual do Ibitipoca, Minas Gerais, Brasil. Dissertação 50f., Universidade Federal de Lavras, Minas Gerais.

Kalamees, R. \& Zobel, M. 1998. Soil seed bank composition in different successional stages of a species rich wooded meadow in Laelatu, western Estonia. Acta Oecologica 19(2): 175-180. Doi: http://dx.doi. org/10.1016/S1146-609X(98)80021-0

Laurance, W.F., Lovejoy, T.E., Vasconcelos, H.L., Bruna, E.M., Didham, R.K., Stouffer, P.C., Gascon, C., Bierregaard, R.O., Laurance, S.G. \& Sampaio, E. 2002. Ecosystem decay of Amazonian forest fragments: a 22-year investigation. Conservation Biology 13(3): 605-618. Doi: http://dx.doi.org/10.1046/j.1523-1739.2002.01025.x.

Lindner, A. 2009. A rapid assessment approach on soil seed banks of Atlantic forest sites with different disturbance history in Rio de Janeiro, Brazil. Ecological Engineering 35: 829-835. Doi: http:// dx.doi.org/10.1016/j.ecoleng.2008.12.006.

Martins, M.A. \& Engel, V.L. 2007. Soil seed banks in tropical forest fragments with different disturbance histories in southeastern Brazil. Ecological Engineering 31: 165-174. Doi: http://dx.doi.org/10.1016/j. ecoleng.2007.05.008.

Melo, A.C.G., Durigan, G. \& Gorenstein, M.R. 2007. Efeito do fogo sobre o banco de sementes em faixa de borda de Floresta Estacional Semidecidual, SP, Brasil. Acta Botanica Brasílica 21(4): 927-934. Doi: http://dx.doi.org/10.1590/S0102-33062007000400017.

Milberg, P. 1995. Soil seed bank after eighteen years of succession from grassland to forest. Oikos 72(1): 3-13. Doi: http://dx.doi. org $/ 10.2307 / 3546031$

Mittermeier, R.A., Gil, P.R., Hoffmann, M., Pilgrim, J., Brooks, J., Mittermeier, C.G., Lamourux, J. \& Fonseca, G.A.B. 2005. Hotspots revisited: earth's biologically richest and most endangered terrestrial ecoregions. Conservation International, London. $391 \mathrm{p}$.

Myers, N., Mittermeier, R.A., Mittermeier, C.G., Fonseca, G.A.B. \& Kent, J. 2000. Biodiversity hotspots for conservation priorities. Nature 403: 853-858. Doi: http://dx.doi.org/10.1038/35002501.

Monaco, L.M., Mesquita, R.C.G. \& Willianson, G.B. 2003. Banco de sementes em uma floresta secundária amazônica dominada por Vismia. Acta Amazonica 33(1): 41-52. Doi: http://dx.doi.org/10.1590/18094392200331052.

Murcia, C. 1995. Edge effects in fragmented forests: implications for conservation. Trends in Ecology \& Evolution 10: 58-62. Doi: http:// dx.doi.org/10.1016/S0169-5347(00)88977-6.

Ribeiro, M.C., Metzger, J.P., Martensen, A.C., Ponzoni, F.J. \& Hirota M.M. 2009. The Brazilian Atlantic Forest: How much is left, and how is the remaining forest distributed? Implications for conservation. Biological Conservation 142: 1141-1153. Doi: http://dx.doi.org/10.1016/j. biocon.2009.02.021.

Rico-Gray, V. \& García-Franco, J.G. 1992. Vegetation and soil seed bank of successional stages in tropical lowland deciduous forest. Journal of vegetation science 3(5): 617-624. Doi: http://dx.doi. org/10.2307/3235828. 
Ries, L., Fletcher Jr., R.J., Batin, J. \& Sisk, T.D. 2004. Ecological responses to habitat edges: Mechanisms, models, and variability explained. Annual Review of Ecology, Evolution, and Systematics 35: 491-522. Doi: http://dx.doi.org/10.1146/annurev.ecolsys.35.112202.130148.

Sandeville Jr., E. 2010. A dinâmica natural das florestas. Paisagem e Ambiente 27: 55-70.

Silva, J.O., Fagan, E.B., Teixeira, W.F., Sousa, M.C. and Silva, Jr. R. 2012. Análise do banco de sementes e da fertilidade do solo como ferramentas para recuperação de áreas perturbadas. Biotemas 25(1): 23-29.

Soares, R.Z.L. \& Almeida, V.P. 2011. Banco de sementes da Floresta Estacional às margens do Reservatório de Itupararanga, VotorantimSP. Revista Eletrônica de Biologia 4(2): 53-72.

Sorreano, M.C.M. 2002. Avaliação de aspectos da dinâmica de florestas restauradas, com diferentes idades. Dissertação 154f., Universidade de São Paulo, São Paulo.

Stevens, S.M. \& Husband, T.P. 1998. The influence of edge on small mammals: evidence from Brazilian Atlantic forest fragments. Biological Conservation 85: 1-8. Doi: http://dx.doi.org/10.1016/ S0006-3207(98)00003-2.

Ururahy, J.C.C., Collares, E.R., Santos, M.M. \& Barreto, R.A.A. 1983. Vegetação: as regiões fitoecológicas, sua natureza e seus recursos econômicos. Estudo fitogeográfico. In . Projeto Radambrasil. Rio de Janeiro, v. 32, p. 553-623.

Vespa, N.I., Zurita, G. \& Bellocq, M.I. 2014. Functional responses to edge effects: Seed dispersal in the southern Atlantic Forest, Argentina. Forest Ecology and Management 328: 310-318.

Zar, J.H. 1984. Biostatistical analysis. Prentice Hall, New Jersey. 718 p. 